\title{
Spectral Distribution of Energy From the Sun
}

\author{
Ralph Stair, Russell G. Johnston, and Thomas C. Bagg
}

\begin{abstract}
Measurements on the spectral energy distribution of direct solar radiation, made in July 1953, at Sacramento Peak, New Mexico, altitude 9,200 feet are described. Spectral data are given for wavelengths extending from 299 to 535 millimicrons for air masses 0 , 1.0, 2.0, and 3.0. A determination of atmospheric transmittance as a function of wavelength results in calculated total amounts of ozone approximating 0.21 centimeter (ntp) as a mean for 4 days during July. Preliminary measurements, employing a lead sulfide photoconducting cell, in the visible and infrared spectrum are discussed. On the basis of the spectral ultraviolet data obtained, an estimate of a value slightly exceeding 2.00 langleys per minute for the solar constant is indicated.
\end{abstract}

\section{Introduction}

Measurements on the spectral distribution of the ultraviolet radiant energy from the sun obtained at Climax, Colo. in September 1951 [1] ${ }^{1}$ indicated appreciable higher intensities outside the earth's atmosphere than had been reported previously. This was not only of some concern to the authors but also of interest to others. Data on the transmittance of radiant energy through the atmosphere- to which the methods and results of the measurement of solar energy contribute - are important to the work of the Air Force Cambridge Research Center. ${ }^{2}$ It has a bearing on a more precise evaluation of the solar constant. This common interest resulted in plans to repeat the measurements under conditions that should be more favorable. Through the courtesy of John W. Evans, director, the Sacramento Peak Observatory was made available for this work during late June and early July of the summer of 1953.

Sacramento Peak is located on the east edge of the New Mexico-White Sands desert area. This station was established by Harvard University after an extensive survey had shown it to be one of the more promising locations in the southwest for use in the study of solar radiation. It is located at an altitude of 9,200 feet within a forest of Ponderosa pine and Douglas fir on a relatively level area of possibly 100 acres. Because this location is not the highest within the region, some of the summer thunderstorms and associated cloudiness miss the observing station.

\section{Instruments and Procedure}

The instrumental arrangement for this work was similar to that employed at Climax [1]. However, not only was no single piece of equipment employed at Climax taken to Sacramento Peak, except for the type 935 phototube, but also even a new standard of spectral radiant enorgy independently calibrated was employed in the calibrations of the equipment.

\footnotetext{
1 Figures in brackets indicate the literature references at the end of this paper.

2 This work was sponsored in part by the Air Force Cambridge Research Center.
}

The spectrometer employed was a double prism mirror instrument manufactured by Carl Leiss of Berlin, Germany. This instrument uses two $30^{\circ}$ quartz prisms, through each of which the radiant energy makes a double pass. The collimating mirrors are of simple spherical design coated with aluminum. The slits are each manually adjustable. All three slits are straight, but being only $7 \mathrm{~mm}$ in length, little error is introduced thereby. Each slit was set at a width of $0.30 \mathrm{~mm}$ throughout the course of the investigation. Changes in wavelength were accomplished through the use of a synchronous-motor drive attached to the wavelength drum. This unit permits recording at any one of three speeds, forward or reverse. A built-in clutch allows quick resetting of the wavelength drum, so that any part of the spectrum may be repeated at will. As the calibrating factors are slightly different for the two directions of operation, all measurements were made with increasing wavelength. Cams are provided to stop the instrument automatically at either end of the wavelength range and to provide, by means of an auxiliary pen, wavelength marks at suitable positions (specific wavelengths through the spectrum) on the recorder chart.

The light beam was modulated at $510 \mathrm{c} / \mathrm{s}$ and the output of the phototube fed into a tuned amplifier of design similar to that previously employed [1, 2, 3]. A strip recorder was again used to plot automatically the spectral data.

A new heliostat, designed with mirrors larger than those in the Climax instrument, was employed in this work. It is of simple design, and arranged so that an aluminized primary plane mirror reflects the beam of light along the polar axis of the instrument. Micrometer adjustments permit accurate settings for declination, latitude, and for them corrections. A second mirror set in a stationary position reflects the light beam horizontally into the spectroradiometer. Thus each of the mirrors operated at fixed angles relative to the light beam during all hours of the day, so that corrections for light polarization could be easily made.

The entire equipment, except for the heliostat, was set up in the "Large Dome" building just inside 
one of the south windows and arranged so that the entrance slit of the spectroradiometer faced toward the south. The solar light beam was refiected through this window onto the axis of the spectroradiometer. Reference marks on the ceiling provided a guide in making adjustments of the heliostat and auxiliary reflecting mirror as the solar declination slowly changed from day to day during the course of the measurements.

The construction of the Large Dome building was such that the temperature variations within it were small during the course of the day. Most of the time the temperature was between $65^{\circ}$ and $70^{\circ} \mathrm{F}$, and usually the daily rise in temperature was not more than $5^{\circ} \mathrm{F}$.

In accordance with the procedure in previous work [1, 3], no lens or mirror was employed to produce an image of the sun on the entrance slit of the spectroradiometer because an integrated solar energy spectrum was desired. This procedure is possible because of the large amount of energy available. It is furthermore desirable because of the simplicity of the reduction of the data through comparing readings on the sun directly with similar data taken on a standard tungsten-in-quartz lamp [4]. Figure 1 gives the spectral calibration factor for the complete instrument, based upon this standard of radiant energy. Other details connected with the reduction of the data may be found in the previous report [1].

Often the polarizing characteristics of a spectroradiometer are overlooked. These, however, may produce appreciable errors if not properly accounted for in the reduction of the data. Each mirror surface produces a definite and significant amount of polarization. If all the mirrors were held to the same positions during the experiment, no difficulty would arise. However, the heliostat mirror is rotated through nearly $180^{\circ}$ during the course of the day from soon after sunrise to before sunset.

This results in an appreciable variation in spectroradiometer transmittance because of polarization of

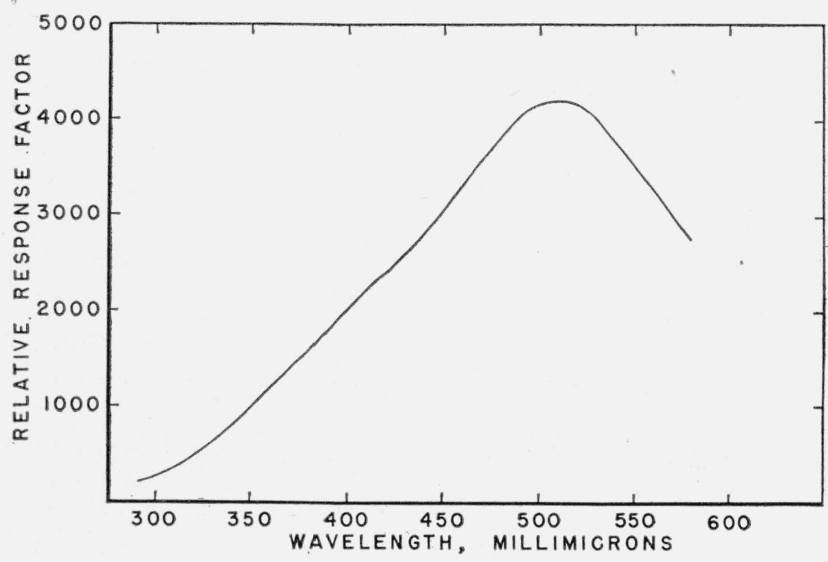

Figure 1. Relative spectral-response factors for the complete spectroradiometer as employed in the Sacramento Peak measurements, by using a 935 phototube and with slit settings of $0.30 \mathrm{~mm}$.

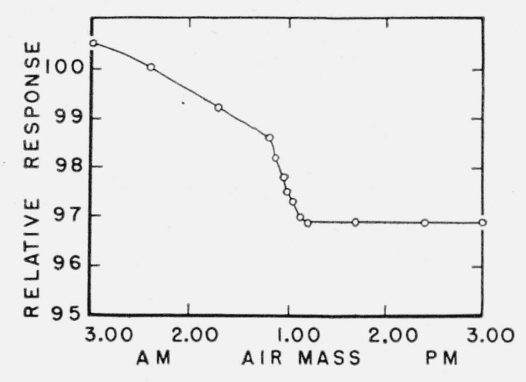

Figure 2. Relative response of the complete equipment as affected by light polarization by the heliostat and spectrometer as a function of air mass during the New Mexico measurements.

the reflected light beam. The magnitude of this effect and the correction to be applied to the data are given in figure 2 .

\section{Ultraviolet Spectral Solar Energy Curve}

Because the measurement of the solar spectral energy requires that the data be taken on the sun while it is moving to a higher or lower altitude, hence, to positions wherein the rays come through greater or lesser amounts of the atmosphere, the recorded spectra change in intensity and in spectral quality from minute to minute. Furthermore, any dust, water vapor, or other impurities within the atmosphere result in further intensity changes at the detector. Therefore, it is advantageous to make the measurements at high altitudes in a dry climate above much of the normal atmospheric contamination.

Data on the ultraviolet spectral radiant energy from the sun were taken on all clear days from the latter part of June until after July 10. Desert dust storms, together with rainy and cloudy weather, prevented measurements on part or all of many days during this period. However, on four days (July $4,5,9$, and 10) the sky was exceptionally clear for part or most of the day. The data for these days have been reduced in a manner similar to that previously employed [1] and are tabulated in table 1 for air masses $0,1.0,2.0$, and 3.0 at various wave lengths corresponding to minimum, maximum, or inflections in the Fraunhofer structure of the solar spectrum. Each of the values listed in columns 2 to 5 , inclusive, was obtained as a mean representative of all the observations at those particular wave lengths for the days listed. The data for each of these wave lengths were extrapolated to air mass 0 in the determination of the solar-energy curve outside the earth's atmosphere. The values for the intermediate wave lengths were obtained by a method of interpolation based on the use of the best noontime observations. The spectral radiant intensities for air masses 1.00 and 0 are shown graphically in figure 3 , and the integrated intensities for $5-\mathrm{m} \mu$ bands are tabulated in table 2. The data for air mass 1.00 represent a slight extrapolation because the lowest 
TABLE 1. Spectral distribution of radiant energy from the sun for selected air masses, Sacramento Peak, N. Mex. Altitude $9,200 \mathrm{ft}$. Mean for 4 days in July 1953. Radiant energy in microwatts per square centimeter per 10 millimicrons.

\begin{tabular}{|c|c|c|c|c|c|c|c|c|c|}
\hline 1 & 2 & 3 & 4 & 5 & 6 & 7 & 8 & 9 & 10 \\
\hline $\begin{array}{l}\text { Wave- } \\
\text { length }\end{array}$ & $\begin{array}{c}\text { July } 4 \\
\text { Air mass } \\
1.00\end{array}$ & $\begin{array}{c}\text { July } 5 \\
\text { Air mass } \\
\quad 1.00\end{array}$ & $\begin{array}{c}\text { July } 9 \\
\text { Air mass } \\
\quad 1.00\end{array}$ & $\begin{array}{c}\text { July } 10 \\
\text { A ir mass } \\
\quad 1.00\end{array}$ & $\begin{array}{c}\text { Mean } \\
\text { Air mass } \\
1.00\end{array}$ & $\begin{array}{c}M_{0} \\
\text { factor }\end{array}$ & $\begin{array}{c}I_{0} \\
\text { Air mass } \\
0\end{array}$ & $\begin{array}{c}\text { Air mass } \\
2.00\end{array}$ & $\begin{array}{c}\text { Air mass } \\
3.00\end{array}$ \\
\hline $\begin{array}{l}\quad m \mu \\
299 \\
299.5 \\
302.5 \\
304 \\
306\end{array}$ & $\begin{array}{r}24.0 \\
42.8 \\
85.5 \\
120.4\end{array}$ & $\begin{array}{r}21.2 \\
39.0 \\
86.5 \\
115.2\end{array}$ & $\begin{array}{r}9.1 \\
19.4 \\
35.0 \\
85.5 \\
121.9\end{array}$ & $\begin{array}{r}64.5 \\
108.1\end{array}$ & $\begin{array}{r}9.1 \\
21.5 \\
39.0 \\
80.5 \\
116.4\end{array}$ & $\begin{array}{c}50 \\
45 \\
20 \\
12 \\
7.8\end{array}$ & $\begin{array}{l}455 \\
968 \\
780 \\
966 \\
908\end{array}$ & $\begin{array}{r}0.18 \\
.48 \\
1.95 \\
6.71 \\
14.9\end{array}$ & $\begin{array}{r}0.01 \\
.10 \\
.56 \\
1.91\end{array}$ \\
\hline $\begin{array}{l}309.2 \\
310 \\
312 \\
314.9 \\
315.8\end{array}$ & $\begin{array}{l}176.6 \\
310 \\
\end{array}$ & $\begin{array}{l}187.9 \\
303 \\
\end{array}$ & $\begin{array}{l}178.0 \\
325 \\
\end{array}$ & $\begin{array}{c}174.5 \\
287 \\
\end{array}$ & $\begin{array}{l}205.6 \\
179.3 \\
306 \\
340 \\
372\end{array}$ & $\begin{array}{l}5.5 \\
5.1 \\
4.3 \\
3.4 \\
3.2\end{array}$ & $\begin{array}{r}1,131 \\
914 \\
1,316 \\
1,156 \\
1,190\end{array}$ & $\begin{array}{r}37.4 \\
35.2 \\
71.2 \\
100.0 \\
116.3\end{array}$ & $\begin{array}{r}6.80 \\
6.89 \\
16.5 \\
29.4 \\
36.3\end{array}$ \\
\hline $\begin{array}{l}316.5 \\
317.9 \\
318.5 \\
321.1 \\
321.7\end{array}$ & $\begin{array}{c}323 \\
424 \\
\end{array}$ & $\begin{array}{c}334 \\
424 \\
-\end{array}$ & $\begin{array}{c}346 \\
435 \\
\end{array}$ & $\begin{array}{c}330 \\
401 \\
\end{array}$ & $\begin{array}{l}333 \\
463 \\
421 \\
523 \\
495\end{array}$ & $\begin{array}{l}3.1 \\
2.92 \\
2.85 \\
2.59 \\
2.53\end{array}$ & $\begin{array}{l}1,032 \\
1,352 \\
1,200 \\
1,355 \\
1,252\end{array}$ & $\begin{array}{l}107 \\
159 \\
148 \\
202 \\
196\end{array}$ & $\begin{array}{l}34.7 \\
54.3 \\
51.8 \\
78.0 \\
77.3\end{array}$ \\
\hline $\begin{array}{l}322.8 \\
323.5 \\
325.5 \\
327.5 \\
328.5\end{array}$ & 445 & $\begin{array}{c}451 \\
703 \\
\end{array}$ & $\begin{array}{c}463 \\
708 \\
\end{array}$ & 431 & $\begin{array}{l}479 \\
448 \\
548 \\
706 \\
692\end{array}$ & $\begin{array}{l}2.43 \\
2.40 \\
2.26 \\
2.18 \\
2.15\end{array}$ & $\begin{array}{l}1,164 \\
1,075 \\
1,238 \\
1,539 \\
1,488\end{array}$ & $\begin{array}{l}197 \\
187 \\
242 \\
324 \\
322\end{array}$ & $\begin{array}{r}81.1 \\
77.8 \\
107.3 \\
148.6 \\
149.7\end{array}$ \\
\hline $\begin{array}{l}330.3 \\
331.5 \\
332.9 \\
333.6 \\
335.3\end{array}$ & $\begin{array}{c}684 \\
\end{array}$ & $\begin{array}{c}710 \\
-10 \\
\end{array}$ & $\begin{array}{c}736 \\
\end{array}$ & 689 & $\begin{array}{l}778 \\
705 \\
708 \\
696 \\
727\end{array}$ & $\begin{array}{l}2.09 \\
2.05 \\
2.02 \\
2.00 \\
1.97\end{array}$ & $\begin{array}{l}1,626 \\
1,445 \\
1,430 \\
1,392 \\
1,432\end{array}$ & $\begin{array}{l}372 \\
344 \\
351 \\
348 \\
369\end{array}$ & $\begin{array}{l}178 \\
168 \\
174 \\
174 \\
187\end{array}$ \\
\hline $\begin{array}{l}337 \\
340.8 \\
341.7 \\
343.5 \\
345\end{array}$ & $\begin{array}{c}604 \\
612\end{array}$ & $\begin{array}{c}607 \\
628\end{array}$ & $\begin{array}{c}616 \\
660\end{array}$ & $\begin{array}{c}592 \\
600\end{array}$ & $\begin{array}{l}605 \\
745 \\
717 \\
730 \\
625\end{array}$ & $\begin{array}{l}1.94 \\
1.87 \\
1.86 \\
1.84 \\
1.82\end{array}$ & $\begin{array}{l}1,174 \\
1,393 \\
1,334 \\
1,343 \\
1,138\end{array}$ & $\begin{array}{l}312 \\
398 \\
385 \\
397 \\
343\end{array}$ & $\begin{array}{l}161 \\
213 \\
207 \\
216 \\
189\end{array}$ \\
\hline $\begin{array}{l}348.6 \\
351.5 \\
352.6 \\
355.1 \\
358\end{array}$ & 616 & 617 & 636 & 569 & $\begin{array}{l}676 \\
759 \\
718 \\
798 \\
609\end{array}$ & $\begin{array}{l}1.78 \\
1.75 \\
1.74 \\
1.72 \\
1.70\end{array}$ & $\begin{array}{l}1,203 \\
1,328 \\
1,249 \\
1,373 \\
1,035\end{array}$ & $\begin{array}{l}380 \\
434 \\
413 \\
464 \\
358\end{array}$ & $\begin{array}{l}213 \\
248 \\
237 \\
270 \\
211\end{array}$ \\
\hline $\begin{array}{l}360 \\
361 \\
363.8 \\
367.1 \\
368.6\end{array}$ & 723 & 748 & 723 & 715 & $\begin{array}{l}751 \\
727 \\
779 \\
907 \\
876\end{array}$ & $\begin{array}{l}1.68 \\
1.67 \\
1.65 \\
1.62 \\
1.61\end{array}$ & $\begin{array}{l}1,262 \\
1,214 \\
1,285 \\
1,469 \\
1,410\end{array}$ & $\begin{array}{l}447 \\
435 \\
472 \\
560 \\
544\end{array}$ & $\begin{array}{l}266 \\
261 \\
286 \\
346 \\
338\end{array}$ \\
\hline $\begin{array}{l}371 \\
375 \\
379.4 \\
380.7 \\
385\end{array}$ & 710 & 717 & 750 & 701 & $\begin{array}{l}879 \\
720 \\
989 \\
903 \\
619\end{array}$ & $\begin{array}{l}1.59 \\
1.56 \\
1.53 \\
1.52 \\
1.49\end{array}$ & $\begin{array}{r}1,398 \\
1,123 \\
1,513 \\
1,373 \\
922\end{array}$ & $\begin{array}{l}553 \\
462 \\
646 \\
594 \\
415\end{array}$ & $\begin{array}{l}348 \\
296 \\
422 \\
391 \\
279\end{array}$ \\
\hline $\begin{array}{l}387.7 \\
391.5 \\
394 \\
396.1 \\
397\end{array}$ & 66 & 701 & 691 & 670 & $\begin{array}{l}767 \\
985 \\
680 \\
914 \\
878\end{array}$ & $\begin{array}{l}1.47 \\
1.45 \\
1.44 \\
1.43 \\
1.42\end{array}$ & $\begin{array}{r}1,127 \\
1,428 \\
979 \\
1,307 \\
1,247\end{array}$ & $\begin{array}{l}522 \\
679 \\
472 \\
639 \\
618\end{array}$ & $\begin{array}{l}355 \\
468 \\
328 \\
447 \\
435\end{array}$ \\
\hline $\begin{array}{l}403.3 \\
406 \\
410 \\
416.8 \\
421\end{array}$ & $\begin{array}{c}1,381 \\
-\cdots \\
\end{array}$ & 1,423 & 1,452 & 1,381 & $\begin{array}{l}1,456 \\
1,409 \\
1,441 \\
1,517 \\
1,525\end{array}$ & $\begin{array}{l}1.39 \\
1.38 \\
1.36 \\
1.34 \\
1.32\end{array}$ & $\begin{array}{l}2,024 \\
1,944 \\
1,960 \\
2,033 \\
2,013\end{array}$ & $\begin{array}{l}1,047 \\
1,021 \\
1,060 \\
1,132 \\
1,155\end{array}$ & $\begin{array}{l}754 \\
740 \\
779 \\
845 \\
875\end{array}$ \\
\hline $\begin{array}{l}424 \\
428 \\
432 \\
436 \\
441\end{array}$ & $\begin{array}{c}1,279 \\
1,560 \\
\end{array}$ & $\begin{array}{c}1,297 \\
1,578 \\
\end{array}$ & $\begin{array}{c}1,330 \\
1,627 \\
\end{array}$ & $\begin{array}{l}1,262 \\
1,545 \\
\end{array}$ & $\begin{array}{l}1,502 \\
1,292 \\
1,463 \\
1,578 \\
1,724\end{array}$ & $\begin{array}{l}\text { 1. } 31 \\
1.31 \\
1.30 \\
1.29 \\
1.275\end{array}$ & $\begin{array}{l}1,968 \\
1,693 \\
1,902 \\
2,036 \\
2,198\end{array}$ & $\begin{array}{r}1,147 \\
986 \\
1,125 \\
1,223 \\
1,352\end{array}$ & $\begin{array}{r}875 \\
753 \\
866 \\
948 \\
1,061\end{array}$ \\
\hline $\begin{array}{l}477 \\
455.7 \\
468 \\
482 \\
487\end{array}$ & $\begin{array}{c}1,814 \\
1,668 \\
1,529\end{array}$ & $\begin{array}{c}1,835 \\
1,676 \\
1,543\end{array}$ & $\begin{array}{c}1,869 \\
1,727 \\
1,556\end{array}$ & $\begin{array}{c}1,785 \\
1,657 \\
1,526\end{array}$ & $\begin{array}{l}1,826 \\
1,864 \\
1,682 \\
1,721 \\
1,539\end{array}$ & $\begin{array}{l}1.26 \\
1.24 \\
1.23 \\
1.21 \\
1.21\end{array}$ & $\begin{array}{l}2,301 \\
2,311 \\
2,069 \\
2,082 \\
1,862\end{array}$ & $\begin{array}{l}1,449 \\
1,503 \\
1,367 \\
1,422 \\
1,272\end{array}$ & $\begin{array}{l}1,150 \\
1,212 \\
1,112 \\
1,175 \\
1,051\end{array}$ \\
\hline $\begin{array}{l}497 \\
500 \\
509 \\
520 \\
526\end{array}$ & $\begin{array}{c}1,605 \\
1,613 \\
\end{array}$ & $\begin{array}{c}1,601 \\
1,635 \\
\end{array}$ & $\begin{array}{c}1,631 \\
1,636 \\
\end{array}$ & $\begin{array}{c}1,598 \\
1,594 \\
\end{array}$ & $\begin{array}{l}1,647 \\
1,609 \\
1,678 \\
1,620 \\
1,687\end{array}$ & $\begin{array}{l}1.20 \\
1.195 \\
1.185 \\
1.18 \\
1.175\end{array}$ & $\begin{array}{l}1,976 \\
1,923 \\
1,988 \\
1,912 \\
1,982\end{array}$ & $\begin{array}{l}1,372 \\
1,346 \\
1,416 \\
1,373 \\
1,436\end{array}$ & $\begin{array}{l}1,144 \\
1,127 \\
1,195 \\
1,163 \\
1,222\end{array}$ \\
\hline $\begin{array}{l}530 \\
535\end{array}$ & 1,723 & 1,731 & $\begin{array}{l}1,701 \\
-\end{array}$ & $\begin{array}{c}1,702 \\
-\end{array}$ & $\begin{array}{l}1,714 \\
1,716\end{array}$ & $\begin{array}{l}1.17 \\
1.165\end{array}$ & $\begin{array}{l}2,005 \\
1,999\end{array}$ & $\begin{array}{l}1,465 \\
1,473\end{array}$ & $\begin{array}{l}1,252 \\
1,264\end{array}$ \\
\hline
\end{tabular}




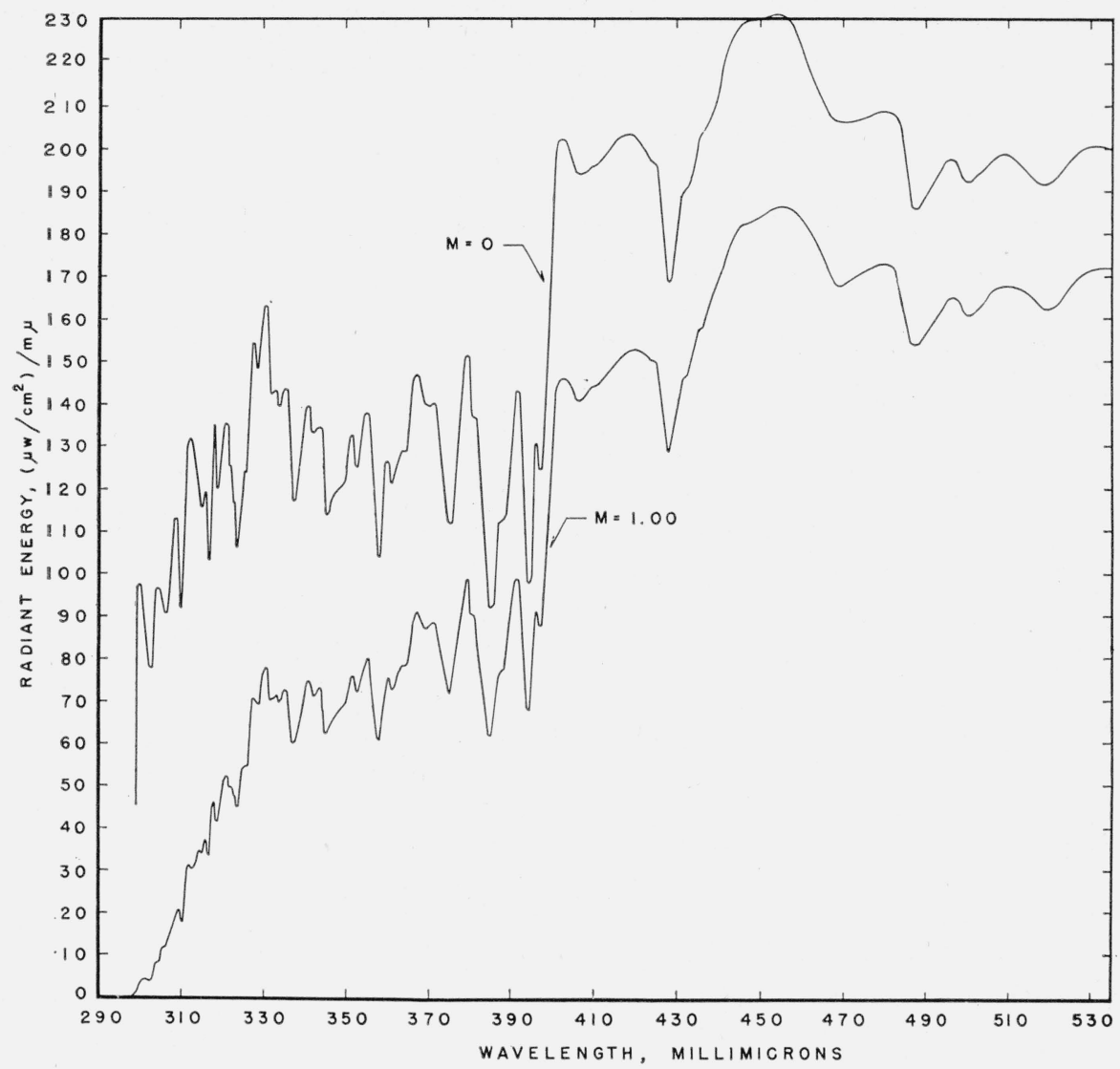

Figure 3. Spectral distribution of radiant energy from the sun, based on the measurements for 4 days in July 1953, Sacramento Peak, N. Mex., altitude 9,200 feet.

TABLE 2. Integrated spectral distribution of radiant energy from the sun for air masses 0 and 1.00

Evaluation made from data of table 1. Radiant energy is expressed in microwatts per square centimeter for $5 \mathrm{~m} \mu$ bands.

\begin{tabular}{|c|c|c|c|c|c|}
\hline 1 & 2 & 3 & 1 & 2 & 3 \\
\hline $\begin{array}{c}\text { Center of } \\
\text { wavelength } \\
\text { interval }\end{array}$ & $\begin{array}{l}\text { Air } \\
\text { mass } \\
1.00\end{array}$ & $\underset{0}{\operatorname{mass}}$ & $\begin{array}{c}\text { Center of } \\
\text { wavelength } \\
\text { interval }\end{array}$ & $\begin{array}{c}\text { Air } \\
\text { mass } \\
1.00\end{array}$ & $\begin{array}{c}\text { Air } \\
\text { mass } \\
0\end{array}$ \\
\hline $\begin{array}{c}m \mu \\
302.5 \\
307.5 \\
312.5 \\
317.5 \\
322.5\end{array}$ & $\begin{array}{r}27 \\
78 \\
148 \\
205 \\
250\end{array}$ & $\begin{array}{l}447 \\
503 \\
606 \\
598 \\
605\end{array}$ & $\begin{array}{l}m \mu \\
427.5 \\
432.5 \\
437.5 \\
442.5 \\
447.5\end{array}$ & $\begin{array}{l}676 \\
740 \\
808 \\
884 \\
915\end{array}$ & $\begin{array}{r}888 \\
958 \\
1,034 \\
1,119 \\
1,151\end{array}$ \\
\hline $\begin{array}{l}327.5 \\
332.5 \\
337.5 \\
342.5 \\
347.5\end{array}$ & $\begin{array}{l}331 \\
360 \\
329 \\
357 \\
329\end{array}$ & $\begin{array}{l}725 \\
732 \\
646 \\
657 \\
595\end{array}$ & $\begin{array}{l}452.5 \\
457.5 \\
462.5 \\
467.5 \\
472.5\end{array}$ & $\begin{array}{l}927 \\
926 \\
893 \\
848 \\
845\end{array}$ & $\begin{array}{l}1,157 \\
1,142 \\
1,088 \\
1,033 \\
1,034\end{array}$ \\
\hline $\begin{array}{l}352.5 \\
357.5 \\
362.5 \\
367.5 \\
372.5\end{array}$ & $\begin{array}{l}374 \\
345 \\
379 \\
439 \\
410\end{array}$ & $\begin{array}{l}654 \\
594 \\
629 \\
710 \\
645\end{array}$ & $\begin{array}{l}477.5 \\
482.5 \\
487.5 \\
492.5 \\
497.5\end{array}$ & $\begin{array}{l}863 \\
849 \\
775 \\
799 \\
817\end{array}$ & $\begin{array}{r}1,041 \\
1,033 \\
942 \\
962 \\
979\end{array}$ \\
\hline $\begin{array}{l}377.5 \\
382.5 \\
387.5 \\
392.5 \\
397.5\end{array}$ & $\begin{array}{l}435 \\
391 \\
376 \\
419 \\
498\end{array}$ & $\begin{array}{l}671 \\
595 \\
553 \\
604 \\
705\end{array}$ & $\begin{array}{l}502.5 \\
507.5 \\
512.5 \\
517.5 \\
522.5\end{array}$ & $\begin{array}{l}811 \\
836 \\
836 \\
815 \\
822\end{array}$ & $\begin{array}{l}970 \\
991 \\
982 \\
958 \\
970\end{array}$ \\
\hline $\begin{array}{l}402.5 \\
407.5 \\
412.5 \\
417.5 \\
422.5\end{array}$ & $\begin{array}{l}723 \\
710 \\
733 \\
760 \\
757\end{array}$ & $\begin{array}{r}1,004 \\
974 \\
993 \\
1,016 \\
995\end{array}$ & $\begin{array}{l}527.5 \\
532.5\end{array}$ & $\begin{array}{l}850 \\
859\end{array}$ & $\begin{array}{r}997 \\
1,002\end{array}$ \\
\hline
\end{tabular}

air mass actually encountered during the course of the measurements was approximately 1.01 at apparent noon.

If a comparison is made between these data and those for Climax, Colo., in September 1951, it should be in terms of the data for air mass 0 becuase for larger air masses the data are not directly comparable as there is an altitude difference between the two stations. This difference in air masses results in slightly different magnitudes of Rayleigh scattering. In general, the two sets of data are in agreement within about 5 percent, the new values being slightly higher in the visible spectrum but slightly lower for wavelengths shorter than about $330 \mathrm{~m} \mu$. Agreement is close between about 330 and $400 \mathrm{~m} \mu$. As the two sets of data were obtained at different locations and at different seasons of the year with different spectroradiometric equipment independently calibrated, it is felt that the results are accurate within the limits of the experimental variations indicated in the tabulated data for the various days covered by the observations in the two cases. However, as the later data were obtained during July, a correction $(3.4 \%)$ was necessarily required to reduce them to the mean solar distance. As the sun was at approximately the mean solar distance when the September 1951 data were obtained, no correction was required in that case. 


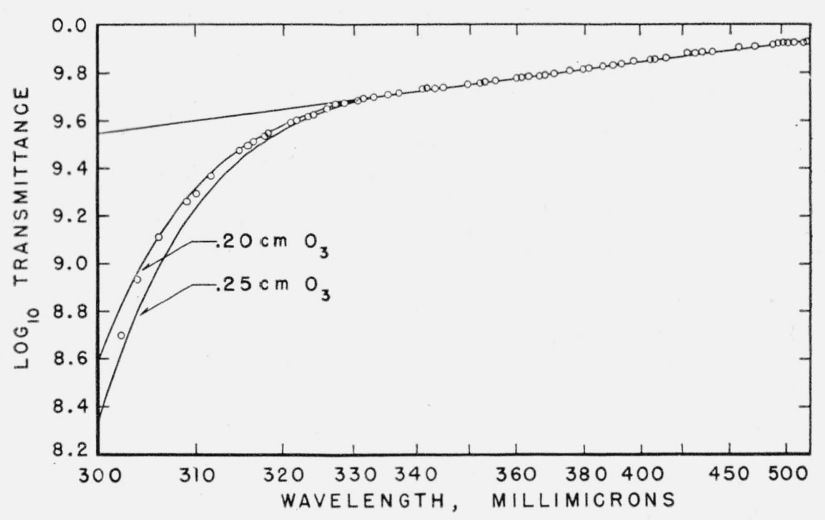

FIgure 4. Atmospheric transmittance at Sacramento Peak, N. Mex., altitude 9,200 feet; also determination of total ozone above the observing station.

Upper curve, scattering; lower curves, ozone; circles, atmospheric transmittance; air mass, 1.00; wavelength scale as a function of $-(\mu-)^{2} \lambda^{-4}$.

\section{Atmospheric Transmittance and Ozone}

Following the same procedures employed in the previous publication [1], the atmospheric transmission curve for Sacramento Peak, N. Mex., depicted in figure 4, was determined on the basis of the average of the data for the 4 days (July 4, 5, 9, and 10) given in table 1. In this illustration the logarithms of the observed transmittances of unit atmosphere for the different wavelengths are plotted as a function of the wavelength, which in turn is expanded [5] according to the funcion $-(\mu-1)^{2} \lambda^{-4}$ of the Rayleigh law of molecular scattering,

$$
\log \mathrm{TR}_{\mathbf{R}}=-\frac{32 \pi^{3}(\mu-1)^{2} H \log e}{3 N \lambda^{4}},
$$

in which $\lambda$ is the wavelength of the radiant energy, and $\mu$ is the index of refraction of the atmosphere. As the atmospheric depth, $H$, and the molecular density, $N$, for the zenith position are constant, the resulting plot of the logarithm of the atmospheric transmittances becomes a straight line in those spectral regions wherein the Rayleigh law of pure scattering is applicable.

Again, the data given by Fabry and Buisson [6] were employed in the calculation of the two curves (fig. 4) representing amounts of ozone required for a similar amount of optical absorption. On the basis of these data, about $0.21 \mathrm{~cm}$ of ozone (ntp) was present from July 4 to July 10 at Sacramento Peak, N. Mex. This is in good agreement with previous measurements for the same season of the year for a similar latitude [7].

\section{Preliminary Measurements of the Spectral Solar Radiation Between 500 and 2,500 Millimicrons}

Although July weather at Sacramento Peak is not especially suitable for the study of the solar spectrum, especially in the infrared region, an opportunity was afforded on several days to make some preliminary measurements by the substitution of a lead sulfide cell for the 935 phototube. Otherwise, the spectroradiometric and recording equipment was unchanged.

Among the interesting results of this preliminary work, it was found that the PbS cell was sufficiently sensitive for use in the ultraviolet (down to about $310 \mathrm{~m} \mu$ ) and visible regions of the solar spectrum, as well as in the infrared out to about $2,500 \mathrm{~m} \mu$. Large changes in the water-vapor absorption bands indicated the high sensitivity of this equipment and its possible great usefulness in water-vapor studies or for the routine recording of the total water content of the atmosphere. On some days a doubling of the total atmospheric water vapor occurred within a matter of minutes. Generally, on the days on which observations were made, the water vapor increased rapidly until the sky was clouded over.

Figure 5 shows some typical recorder records extending from the ultraviolet to about $2,500 \mathrm{~m} \mu$ in the infrared. No attempt has been made, however, to evaluate these records for spectral radiant energy. Although comparative data were taken with the tungsten-in-quartz lamp, the large variations in the over-all photoelectric sensitivity, together with a lack of precise knowledge of the spectral-energy distribution of the lamp standard, preclude the precise evaluation of these data. Also, the large variations in atmospheric water vapor during the course of the measurements rule out any extrapolation to zero air mass within those parts of the spectrum in which water-vapor absorption is pronounced. The data are given simply to illustrate what may be accomplished in this field under the proper conditions, namely, with a detector standardized for sensitivity (may be temperature controlled), in a relatively dry atmosphere (at least at nearly constant humidity), and with a suitable standard of spectral radiant energy. These requirements should exact little difficulty of fulfillment. The first can be met through a careful study and/or selection of the detector employed, the second through proper choice of the season of the year for the particular station, and the third through planned rasearch on emissivities of a suitable lamp standard.

In connection with the study of atmospheric water vapor, changes in the optical absorption of the band located near $1,900 \mathrm{~m} \mu$ is of especial interest. This band is broad, due to the relatively very high absorption for water vapor that occurs at this wavelength. As dispersed by a quartz-prism instrument, this band shows sufficient structure to make its use suitable over a considerable range of humidity values. However, for very high humidities one of the other water bands would be found more suitable for calibration purposes. In figure 6 the general absorption pattern of the $1,900-\mathrm{m} \mu$ water band is shown for a number of times during the morning of July 14. It is to be noted, that, although the air mass was decreasing during the course of these measurements, the absorption character within this band shows that the amount of water vapor in the solar beam was actually increasing between about 


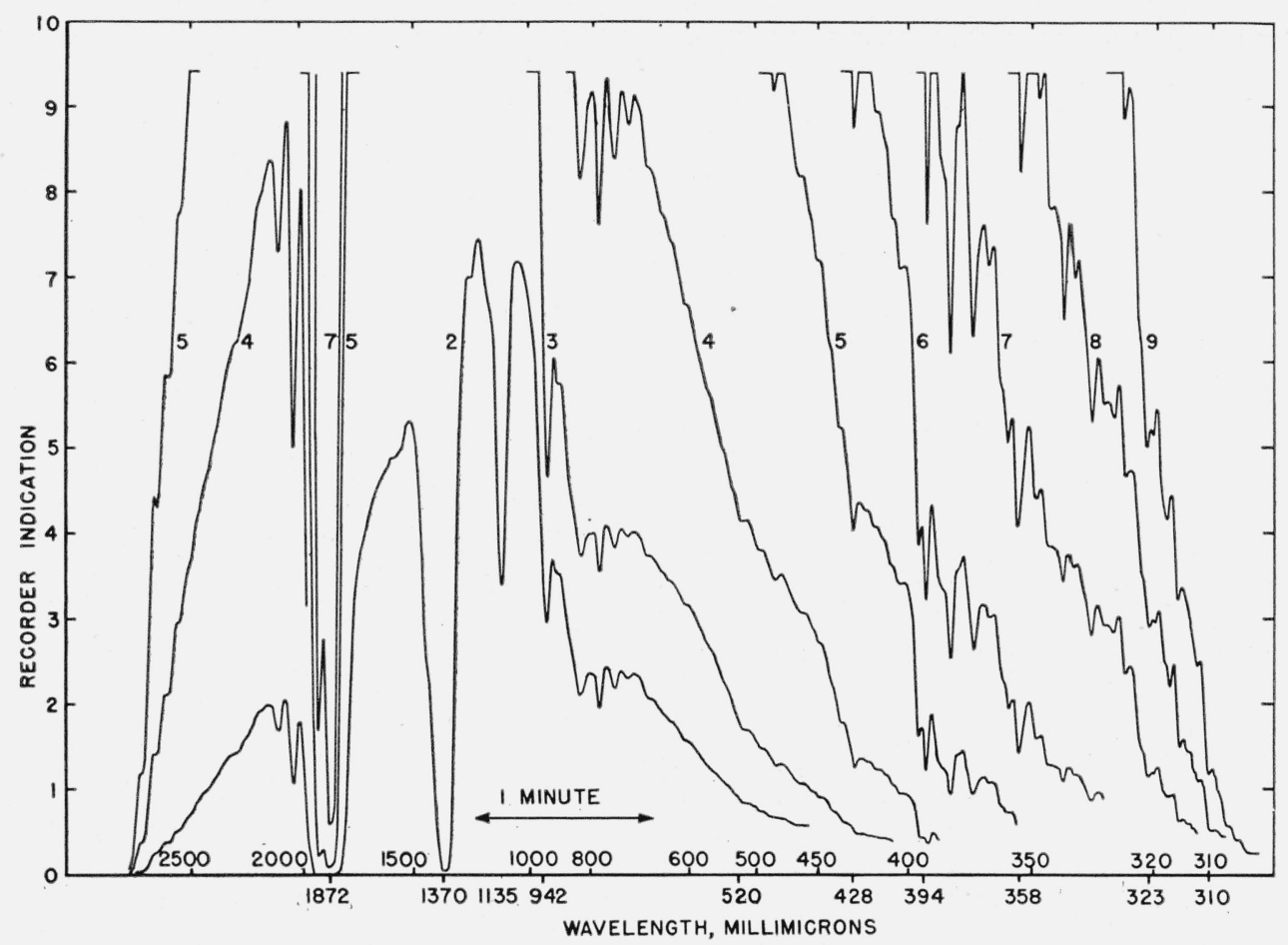

FIGURE 5. Representative data taken from a section of the recorder chart while employing the $\mathrm{PbS}$ cell as detector.

July 15,1953 , approximately 10:00 a. $\mathrm{m}$. The numbers on the chart refer to amplifier sensitivity settings. The data illustrated cover a recording time of approximately 18 minutes.

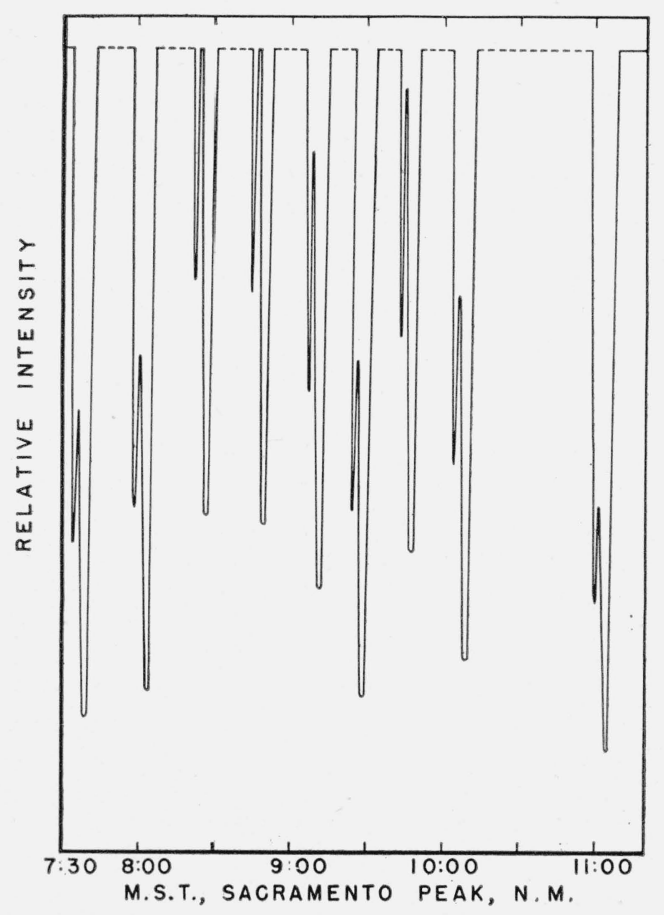

Figure 6. Recorder tracings for the watervapor absorption within the 1,900-m $\mu$ band during the morning of July 14.

See curve 7 of figure 5 for similar data at 10:00 a. m. on July 15.
8:30 and 11:00 a.m. When correction for pathlength through the atmosphere is made, the true water vapor increase is even greater than indicated by the recorded data.

\section{Present Status of the Solar Constant as Indicated by the Sacramento Peak Data}

The solar constant, defined as the number of gramcalories per square centimeter (langleys) per minute received from the sun at mean solar distance, is a measure of the total radiant energy emitted by the sun, and hence is one of the primary constants of astrophysics. Little work toward the establishment of the value of this constant has been done by workers outside the Smithsonian Institution of Washington. Hence the generally accepted value of 1.946 langleys per minute is based primarily upon the work of C. G. Abbot and his associates [8, 9]. Although their work was outstanding in this field at that time, the current need of certain revisions has been suggested by Schatzman [10], Allen [11], Nicolet [12], Georgi [13], Houghton [14], and others. Two points have been noted wherein the published data may be in need of revision, namely, (a) the need for the establishment of a precise spectral radiant-energy distribution for the entire solar spectrum reaching the earth's surface, and (b) careful evaluation of the solar energy in the ultraviolet and infrared regions of the spectrum, which, because of absorption within the 
atmosphere, does not penetrate to the earth's surface. The methods employed and the use of the data by the Smithsonian Institution observers did not require precise spectral-energy determinations. They were interested primarily in variations of the solar constant with time. Hence there remains a question regarding the magnitude of any ultraviolet or infrared corrections until precise spectral radiant-energy data are available.

The spectral solar-energy distribution within the range of 346 to $2,400 \mathrm{~m} \mu$ (containing approximately 90 percent of the total solar radiant energy), as employed by the Smithsonian Institution, is generally accepted as being approximately correct. Also, the present measurements are in close agreement with these data within the spectral range of 400 to $500 \mathrm{~m} \mu$. In the ultraviolet spectrum, however, the New Mexico and Colorado measurements [1] indicate a considerably higher radiant-energy emission from the sun. It is estimated that with the use of these data, supplemented by new rocket data $[15,16]$ for the shorter wavelengths, together with a reevaluation of the infrared above $2,400 \mathrm{~m} \mu$, that the value of the solar constant will be found to be slightly above 2.00 langleys per minute.

\section{Summary and Conclusions}

From the data obtained, the spectral distribution of the radiant energy from the sun, between 299 and $535 \mathrm{~m} \mu$, has been determined for various air masses at the earth's surface (altitude 9,200 feet) and for outside the earth's atmosphere. The latter is in close agreement with data obtained at Climax, Colo., in 1951. From the changes in spectral intensity as a function of air mass (solar angle), the atmosphereic transmission coefficients and the total atmospheric ozone content $(0.21 \mathrm{~cm})$ have been determined as a mean of the measurements for 4 days in July 1953 at Sacramento Peak, N. Mex. These data are in good agreement with the best published values.

Preliminary measurements were made on the spectral distribution of solar radiation within the visible and infrared spectrum by using a PbS photoconductive cell. Interesting possiblilites are indicated as a result of these observations for a more accurate determination of the spectral solar radiant energy (hence a more accurate establishment of the solar constant) as well as a neat method for use in the study or recording of total atmospheric water-vapor concentration.
A discussion is included relative to the possible value of the solar constant if considered in terms of the higher ultraviolet spectral intensities indicated as the result of this work. An estimated value slightly exceeding 2.00 langleys per minute is indicated.

The authors acknowledge the courtesy of members of the Geophysies Research Directorate of Air Force Cambridge Research Center in contributing to this project, in particular P. R. Gast for helpful assistance; also John W. Evans, Major James Sadler, and other members of the Upper Air Research Observatory, who placed the facilities of the observatory at their disposal and otherwise rendered valuable assistance to us while there.

\section{References}

[1] Ralph Stair, Ultraviolet radiant energy from the sun observed at 11,190 feet, J. Research NBS 49, 227 (1952) RP2357.

[2] Ralph Stair, Photoelectric spectroradiometry and its application to the measurement of fluorescent lamps, J. Research NBS 46, 437 (1951) RP2212.

[3] Ralph Stair, Ultraviolet distribution of radiant energy from the sun, J. Research NBS 46, 353 (1951) RP2206.

[4] R. Stair and W. O. Smith, A tungsten-in-quartz lamp and its applications in photoelectric radiometry, J. Research NBS 30, 449 (1943) RP1543.

[5] Edison Pettit, Spectral energy-curve of the sun in the ultraviolet, Astrophys. J. 91, 159 (1940).

[6] C. Fabry and H. Buisson, Data on ozone absorption, Compt. rend. 19\%, 457 (1931).

[7] Ralph Stair, Seasonal variation of ozone at Washington, D. C., J. Research NBS 43, 209 (1949) RP2022.

[8] C. G. Abbot and others, Annals of the Astrophysical Observatory of the Smithsonian Institution, 2, to 6, $(1908,1913,1922,1932,1942)$; Smithsonian Misc. Collections 74, No. 7 (1923); 92, No. 13 (1934); 110, Nos. 5 and 11 (1948).

[9] L. B. Aldrich and W. M. Hoover, The solar constant, Science 116, 3 (1952).

[10] E. Schatzman, Sur la valeur de la constante solaire, Ann. astrophys. 12, 305 (1949).

[11] C. W. Allen, The solar constant, The Observatory 70, 154 (1950).

[12] M. Nicolet, Sur le probleme de la constante solaire, Ann. astrophys. 14, 249 (1951).

[13] J. Georgi, Sokarkonstante und meteorologische Strahlungmessung, Ann. Meteorol. 3-5, 83 (1952).

[14] H. G. Houghton, The solar constant, J. Meteorol. 8, 270 (1951).

[15] E. O. Hulburt, The upper atmosphere of the earth, J. Opt. Soc. Am. 3\%, 405 (1947).

[16] E. Durand, Rocket sonde research at the Naval Research Laboratory, page 134; G. P. Kuiper, The atmospheres of the earth and planets (Univ. of Chicago Press, 1949).

Washington, March 16, 1954. 